\title{
The Anthropocene: scientific meaning and philosophical significance
}

doi) https://doi.org/10.21814/anthropocenica.3097

\begin{abstract}
The "Anthropocene" is a relatively new and unprecedented concept, used to signify the most recent chapter in Earth History in which our species has become a major geological and geomorphic agent, and a controversial hypothesis stating that this new state of our planet constitutes a scientific fact. Both claims are being debated within the Geosciences, but also in the fields of the Social Sciences and the Humanities. This paper aims to produce some insight on the complementary topics of: (a) the meaning of the Anthropocene as a scientific concept and hypothesis; (b) its philosophical significance, namely, what ontological entity is the Anthropocene and how do we have epistemological access to it.
\end{abstract}

Keywords: Anthropocene - Hyperobject - Technical image - Timothy Morton - Vilem Flusser

Resumo: O "Antropoceno" é um conceito relativamente novo e sem precedentes, usado para significar o capítulo mais recente da História da Terra no qual a nossa espécie se tornou um importante agente geológico e geomórfico, assim como uma hipótese polémica que afirma que este novo estado de nosso planeta constitui um facto. Ambas as reivindicações vêm sendo debatidas no âmbito das Geociências, mas também na área das Ciências Sociais e Humanas. Este artigo tem como objetivo produzir alguma luz sobre os tópicos complementares de: (a) o significado do Antropoceno como um conceito e uma hipótese científicos; (b) a sua relevância filosófica, a saber, que entidade ontológica é o Antropoceno e como temos acesso epistemológico a ele.

Palavras-chave: Antropoceno - Hiperobjeto - Imagem técnica - Timothy Morton - Vilem Flusser
João Ribeiro

Mendes

Departamento de Filosofia,

Universidade do Minho

Institute for Anthropocene

Studies

Portugal

\jcrmendes@ilch.uminho.pt

iD 0000-0003-3731-2246 


\section{João Ribeiro Mendes}

\section{What is the Anthropocene?}

\subsection{A geological concept.}

The Anthropocene is a concept, i.e., a word embodying an idea used within an established intellectual and cultural framework - or, as Ian Hacking said «A concept is nothing other than a word in its sites» ([1984] 2002, p. 17). Two Ancient Greek terms were used in its composition: "anthropos" (őv $\theta \rho \omega \pi 0 \varsigma)$ meaning "human" and "kainos"

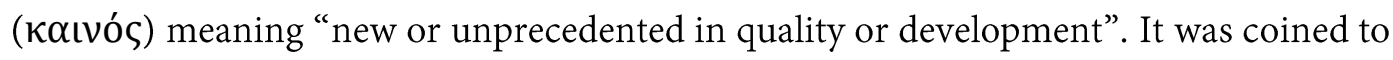
convey the idea that we have already entered a new chapter in the history of our planet in which our species has become a key geological and geomorphic agent, one with the power to induce geophysical effects similar to or greater than the global forces of nature. ${ }^{1}$

The concept of the Anthropocene made its appearance in the context of the Earth System Science paradigm. ${ }^{2}$

Believing an anecdote told by Will Steffen, the concept was officially presented, for the first time, by Dutch atmospheric chemist Paul Crutzen, in a meeting of the Scientific Committee for the International Geosphere-Biosphere Programme (IGBP) ${ }^{3}$ held at the end of February 2000 in Cuernavaca, Mexico. According to this U.S. climatologist - who was present at the meeting and was at the time chairman of the IGBP - during a discussion about the age and intensity of human impacts on the planet, the 1995 Nobel Prize awarded in chemistry (for his work on the ozone layer), after having listen several scientists of the IGBP's paleo-environmental project, reporting on their latest research, refer repeatedly to the Holocene - the most recent formally recognized geological epoch of Earth history - to set the context for their work, eventually interrupted

\footnotetext{
${ }^{1}$ Some examples of such natural global geophysical forces are: the gravitational pull of the Moon and Sun that gives rise to tides; the gravitational forces that make rocks press down on deeper rocks, increasing their density as the depth increases; the heat flow that generates the Earth's magnetic field - essential to deflect most of the solar wind, whose charged particles would otherwise strip away the ozone layer that protects the Earth from harmful ultraviolet radiation - through the geodynamo and plate tectonics - the structural parts of Earth's - through mantle convection - the motion of Earth's mantle, made of rock and ices, laying below its core and above its crust -; seismic waves, whose vibrations travel through the Earth's layers, resulting from earthquakes, volcanic eruptions, and magma movement.

${ }^{2}$ This cross-disciplinary field emerged in the mid-1980s and since then has been developed mainly by NASA and the International Geosphere-Biosphere Program to study Earth as a system, i.e., as an entity composed of interlocking chemical, climatic, and biological processes of different timescales.

${ }^{3}$ The IGBP was a research program for the study of planetary change on its global scale that lasted from 1987 to 2015.
} 


\section{The Anthropocene: scientific meaning and philosophical significance}

them and claimed: "Stop using the word Holocene. We're not in the Holocene any more. We're in the ... the ... the ...(searching for the right word)... the Anthropocene !" ${ }^{4}$

Crutzen later learned that Eugene Stoermer had independently coined the same word to express the same idea in the 1980s and keep using it informally until the end of the 1990s. ${ }^{5}$ He wrote to the U.S. limnologist, suggesting the joint publication of a paper, which they did in the Global Change Newsletter of the IGBP (Crutzen \& Stoermer, 2000). The concept began in this way to be first disseminated within the Earth System Science community. However, unlike Stoermer, who ever again used it, Crutzen published two years later an article in Nature (Crutzen, 2002) restating the concept and making it known to a much wider scientific community. ${ }^{6}$

Some authors - beginning with Crutzen and Stoermer, Op. cit. - have claimed that, despite the word being of recent coinage, the idea embodied in it eventually goes back to the second volume of the Corso di Geologia published by the priest-geologist Antonio Stoppani in 1873 - who nevertheless used the expression "Era Antropozoica" (Anthropozoic Age) - or even further back to Georges-Louis Leclerc, Comte de Buffon, Les Époques de la Nature (1778), where the French naturalist talks about a "Septième Époque" (Seventh Epoch) or "Époque del'homme” (Epoch of Man).

Other authors, however, argued that the idea itself is unprecedented. According to them, although is shows apparent similarity - "family likenesses" (“Familienähnlichkeit"), would Wittgenstein say - with preceding notions, the concept of the "Anthropocene" has a clearly distinct meaning. Austin Roberts (2018) - a U.S. researcher - summed up the following three main reasons given in support of this position.?

First of all, he says, the concept of the "Anthropocene" is rooted in a theoretical conception of the Earth that conceives of it as a complex system, i.e., as a set of physical, chemical and biological (usually called biogeochemical) cycles of global scale in interaction, plus energy flows, that provide the necessary conditions for life on our planet. This view, called Earth System Science (ESS), as already mentioned, began to be developed

\footnotetext{
${ }^{4}$ See Steffen, 2013, p. 486. Crutzen confirmed the story in the interview he gave to Christian Schwägerl (see Schwägerl \& Crutzen 2013). See also Bonneuil \& Fressoz, 2016, p. 3, and Angus, 2016, p. 27-28).

${ }^{5}$ E.g., in 1995 , Stoermer sent an email to some of his colleagues were he described the terrestrial and neritic oceanic production during the "Anthropocene" (see Syvitski, 2012, p. 14).

${ }^{6}$ See the translation of both texts to the Portuguese language that are part of this issue.

${ }^{7}$ See also Federau, 2016, chapter 2. The philosopher Clive Hamilton and the historian of ideas Jacques Grinevald were among the first to dispute the claim found in some early writings - e.g., Crutzen \& Stoermer, 2000; Crutzen, 2002; Crutzen \& Steffen, 2003 - that the word "Anthropocene" gives expression to an idea that is not new. According to them, the concept of "Anthropocene" is a novelty and has no precursors (Hamilton \& Grinewald, 2015).
} 


\section{João Ribeiro Mendes}

in the 1980s and only acquired a paradigmatic status in the Geosciences at the turn to the 21 th century. Given that the concept of the "Anthropocene" gets most of its meaning from the ESS view, we can legitimately infer that it did not exist before the end of the twentieth century, and eo ipso, that the notions which seem to have a "family resemblance" present, in fact, different meanings.

Another reason, says Roberts, is that the concept of the "Anthropocene" implies that the geophysical human activity not only is having an impact that transcends the local level, affecting the larger natural spheres - Lithosphere, Hydrosphere, Biosphere, Atmosphere, and Cryosphere - of our planet, or even the entire Earth System, but also is increasingly destabilizing their normal functioning and making their behaviour more and more hard to predict. ${ }^{9}$

This means that, unlike its supposed previous related notions, the concept of Anthropocene ends up moving away from the prevailing teleological view of Geohistory - based on uniformitarianism, i.e., on the one hand, that Earth evolves by gradual changes, and, on the other hand, that the anthropic principle, the claim that the Universe is designed to be compatible with conscious living beings like humans, is basically true establishing that the transition from the Holocene to the Anthropocene represents a rupture, a radical discontinuity (from relative stability to relative instability), but also that the human species may disappear in the future.

The third reason, according to Roberts, is that none of the other Anthropocene lookalike notions provided enough evidence in support of the claim that we have entered a new chapter in Earth history, but merely have shown how human activity had brought about environmental and climatic changes in certain places or regions. In turn, it is reasonable to believe that just as 540 million years ago, or so, a transition from the Phanerozoic Era to the Palaeozoic occurred - something we know because we have fossil records in geological strata of that first multicellular life explosion - and about 65 million years ago another transition from the Cretaceous to the Palaeocene period (in the Mesozoic Era) took place - probably after meteorites triggered the abrupt end of the dinosaur reign on Earth, confirmed by the presence of Iridium in the geological strata we can, by analogy, likewise reasonably believe that a few millions years from now, the

\footnotetext{
${ }^{8}$ Elisabeth Anscombe preferred that expression to Wittgenstein 's one in the translation she made of his Philosophical Investigations (1953).

9 This also means that the concept of "Anthropocene" should not be reduced either to that of "global warming" or "climate change", because it encompasses and, at the same time, transcends both. It should not be also strictly identified with the notions of "environmental crisis" or "climate crisis", because the disturbances it connotes seem to be of a more permanent and irreversible kind than the temporary nature of those ecological crises.
} 


\section{The Anthropocene: scientific meaning and philosophical significance}

transition to the new geological epoch of the "Anthropocene" will be attested by future geologists showing how artificial radioactive nucleotides recorded in geological layers, resulting from the thermonuclear deflagrations carried out after 1945, can be taken as stratigraphic anthropogenic markers evidencing that change.

In sum, the concept of the Anthropocene is relatively new and unprecedented.

\subsection{A chronogeological/chronostratigraphical hypothesis}

Crutzen \& Stoermer (2000) is not only the locus where the concept of the Anthropocene officially appears, for the first time, in printed form, but also the place where it was used to formulate the following original controversial empirical scientific hypothesis:

Considering (...) major and still growing impacts of human activities on earth and atmosphere, and at all, including global, scales, it seems to us more than appropriate to emphasize the central role of mankind in geology and ecology by proposing to use the term "anthropocene" for the current geological epoch (p. 17).

Putting it more simply: the hypothesis states that "the Anthropocene is real", i.e., that the Holocene ended, giving way to a new state of our planet, and that the International Chronostratigraphic Chart (ICT) has to be revised to accommodate this novel fact. ${ }^{10}$

The hypothesis of the formalization of the Anthropocene as a new geological epoch is being investigated by the Anthropocene Working Group (AWG) of the Subcommission on Quaternary Research (a component body of the International Commission of Stratigraphy that oversees the Geological Time Scale) formed in 2009 under the direction of British geologist Jan Zalasiewicz. ${ }^{11}$

10 The ICT describes the geological time in which the history of the Earth is inscribed. According to this taxonomy, we are in the Phanerozoic Eon (meaning "appearance of life", although incorrectly by reason of a false belief held in the $19^{\text {th }}$ century) which began 541 million years ago. The Phanerozoic had several eras, the last one called the Cenozoic ("new life", i.e., an era when many mammals replaced the dinosaurs), which began 65 million years ago and still lasts. The fourth period of this era, the Quaternary - a time of glacial cycles, megafauna and the evolutionary radiation of the genus Homo - began about 2 million years ago, and had three epochs: the early Pleistocene; the Late Pleistocene beginning about 1 million years ago; and the Holocene beginning about 12 thousand years ago. Eon, era, period, epoch, age, and stage are the rank divisions of the ICT, from higher to lower. The 'Anthropocene' has been proposed as a fourth epoch of the Quaternary.

${ }^{11}$ For the formalization of the Anthropocene as an epoch, a three-step procedure is required: first, a formal proposal from the AWG should be approved by the Subcommission on Quaternary Stratigraphy; second, it should be approved by the International Commission on Stratigraphy; lastly, it should be approved by the International Union of Geological 


\section{João Ribeiro Mendes}

Some have asked: what will happen if the "Anthropocene" is not formalized as a new geological epoch? According to Valentí Rull, in that case, strictly speaking, the use of the concept should be abandoned. However, he added, given that it «(...) is firmly rooted in many professional and public environments (...)» it will more likely continue to «(...) be used in a cultural sense to indicate and call attention to the fact that humankind significantly influences the global environment.» $(2018$, p. 4). Indeed, the International Union of Geological Sciences is going to be asked to make, sooner or later, a scientific decision - based on stratigraphic criteria - about the recognition of the Anthropocene as a geological epoch, but if the decision turns out to be negative, it does not mean that the concept and the hypothesis will become devoid of all scientific interest and value and be banned from the discourse of the Sciences (Natural and Social) and the Humanities, quite the opposite.

The Anthropocene is a complex epistemic object, one that demands a plurality of research programmes, asks for a variety of methodological approaches, requires the cooperation of diverse fields of study, and mobilizes different traditions of inquiry.

At this last more general level, we can conceive an intellectual division of labour for its investigation. On the one hand, the Geosciences (as a branch of the Natural Sciences) aiming to an explanation - discovery of the causes and effects - of the Anthropocene. The Social Sciences, on the other hand, trying to understand its economic, political and cultural reasons and consequences. ${ }^{12}$ Yet on the other hand, the Humanities (History and

Sciences. In the summer of 2016, during the 35th International Geological Congress, held in Cape Town (South Africa), the AWG issued a first opinion on the hypothesis (see University of Leicester-Press Office, 2016), with large consensus, that: (a) the Anthropocene is geologically real and with sufficient scale to be considered part of the ICT; (b) it has more the characteristics of an Epoch rather than an Age/Stage (lower rank division) or a Period/Era (higher tank division); (c) if adopted as an Epoch, that implies the Holocene has terminated, but that we remain within the Quaternary Period and the Cenozoic Era.

${ }^{12}$ There is an ongoing debate about the onset of the Anthropocene, to which social scientists have made important contributions. Six fundamental proposals concerning the beginning of the Anthropocene were made: (a) the "Early Anthropocene" hypothesis that claims it started with the generalization of agriculture and farming about 8000 years ago (Ruddiman, 2003); (b) the "Orbis Spke" hypothesis, claiming the date of 1610 when occurred a drop in global CO2 levels that supposedly was caused by the deaths of millions of native Americans after smallpox and other diseases were imported to the new world by Europeans (Lewis \& Maslin, 2015); (c) at the time of the First Industrial Revolution when large-scale burning of coal launched a long-term rise in atmospheric concentrations of greenhouse gases (e.g., Crutzen \& Stoermer, 2000); (d) between 1945 and 1950 when Atomic bomb tests were carried out and global spread of derived radionuclides took place (Steffen et al, 2011); (e) in 1964, the year in which the peak in radioactive fallout following nuclear weapons testing was observed before the test ban treaty came into force (Lewis \& Maslin, 2015). I will not elaborate here the topic, but I tend to adhere to the proposal of assigning phases to the Anthropocene: (a) an initial one, beginning by the time of the First Industrial Revolution; (b) another one, after the Second World War, with the intensification and acceleration of exploratory activities of planetary resources; (c) and a third one, corresponding to the last three decades or so, when such activities reached global scale. Rice (2017), through philological argumentation, claims that, for now, the word "Anthropocene" should be replaced by the word "Pleonexycene" - Epoch of avarice or greed or excessive desire ( $\pi \lambda \varepsilon \sigma v \varepsilon \xi \xi \alpha$ in Ancient Greek) - and only in the future, if and when humankind, the 


\section{The Anthropocene: scientific meaning and philosophical significance}

Philosophy, in particular) dedicated to the interpretation (examination and assessment) of the ontological, epistemological, ethical and aesthetical implications of the Anthropocene. Its study involves, thus, either as concept or as hypothesis, multidisciplinary and interdisciplinary research. That is why Hare (2015) following Galison (1997) make use of the metaphorical expression "trading zone" to characterize the emerging domain of the Anthropocene Studies.

\section{How it matters to Philosophy}

The concept and the hypothesis of the Anthropocene pose several philosophical questions. Here only two will be articulated, both regarding the nature of concept. One has to do with its denotation: What kind of thing is the Anthropocene? To which category of objects does it belong? The other deals with the way of grasping such an entity: How do we have access to it? Through discovery and description or through invention and composition? The first is an ontological question and the second an epistemological one. However, although they may be thought of separately, or analytically, they actually work in tandem, and it may be more appropriate to consider them onto-epistemological questions.

To tackle the first question, in section $2.1 \mathrm{I}$ will make use of the notion of "Hyperobject” proposed by Morton (2013). In section 2.2, following Pullizzi (2014) following Flusser ([1985] 2011), I will argue that the "Anthropocene" is a "Technical image".

\subsection{The Antropocene as a Hyperobject}

Timothy Morton - called the "philosopher prophet of the Anthropocene" (Blasdel, 2017) - introduced in the last chapter of his The Ecological Thought (2010) the term "hyperobject", later developed it in Hyperobjects: Philosophy and Ecology after the End of the World (2013).

Anthropos, finally becomes fully conscious and responsible of its power over Earth structure and dynamics it should be used. 
According to Morton (2013), the word "Hyperobject" refers, in general, to «(...) things that are massively distributed in time and space (...)» (p. 1, passim), «(..) relative to humans» (idem, p. 1), «(...) invisible (...)» to them (idem, p. 1, passim), and «(..) exert[ing] downward causal pressure on shorter-lived entities.» (idem, p. 67).

Hyperobjects belong to an extra-ordinary class of objects. The prefix "hyper" helps to instantiate a relation of degree between (the wider) class and (the narrower) subclass: there are (normal) objects and Hyperobjects - or Superobjects -, that is, objects above or beyond the normal scale. This is why Morton says that they "are "hyper" in relation to some other entity» (idem, p. 1). However, the intension of the concept, according to the author, also comprises five features.

Their first common property is "viscosity": «(...) they "stick" to beings that are involved with them.» (ibidem), i.e., «[t]hey «are "everywhere and nowhere" up close.» (idem, p. 128). ${ }^{13}$ «We are stuck to hyperobjects (...)», says Morton, but the closer we get to them, the less we know about them, because «(...) viscosity is a direct product of increasing information. The more data we have about hyperobjects the less we know about them - the more we realize we can never truly know them (...)» (idem, p. 180).

A second common property they have is "nonlocality". That means that «[t]hey involve profoundly different temporalities than the human-scale ones we are used to.» (idem: 1) or, in other words, that «(...) any "local manifestation" of a hyperobject is not directly the hyperobject.» (ibidem). Moreover, Morton says that «[h]yperobjects occupy a high-dimensional phase space that results in their being invisible to humans for stretches of time.» (ibidem).

The third one is what he calls "temporal undulation". This property is not easy to grasp. It seems that Hyperobjects being «(...) time-stretched to such a vast extent that they become almost impossible to hold in mind.» (idem, p. 58) lead us to face an odd situation: they span along time, enveloping us and yet they seem to disappear, precisely due to the vast timescale. Moreover, adds Morton, this situation causes us a dilemma: «(...) we have no time to learn fully about hyperobjects. But we have to handle them anyway.» (idem, p. 67).

"Phasing" is the fourth property of Hyperobjects, i.e., «(...) they occupy a highdimensional phase space that makes them impossible to see as a whole on a regular threedimensional human-scale basis.» (idem, p. 70). A “phase space”, according to Morton,

\footnotetext{
${ }^{13}$ The word "viscosity" is derived from the Latin "viscum", meaning a viscous glue made from mistletoe berries. In Physics it is defined as a measure of a fluid 's resistance to flow. A fluid with large viscosity resists motion. A fluid with low viscosity flows
} 


\section{The Anthropocene: scientific meaning and philosophical significance}

can be described as «(...) the set of all possible states of a system.» (idem, p. 71). The number of all possible states of a system - the complexity of its dynamics - is too big for us to even come closer to apprehend it. ${ }^{14}$

The last property of hyperobjects is to «(...) exhibit their effects interobjectively; that is, they can be detected in a space that consists of interrelationships between aesthetic properties of objects.» (idem, p. 1), or, more specifically, that they are «(...) not a function of our knowledge (...)» (idem, p. 2), but a mesh of non-human entities and human entities. $^{15}$

Morton provides several examples of what he considers to be Hyperobjects: global warming (idem, p. 3, passim), Styrofoam ${ }^{16}$ (idem, p. 1, passim), and radioactive plutonium (ibidem).

According to him, they are "Hyperobjects" of the Anthropocene. However, he doesn `t claim, at least explicitly, that the Anthropocene belongs to that same ontological category. Notwithstanding, I want to argue that we can legitimately consider the Anthropocene as a Hyperobject and not just as a concept or framework of thought to make objects of that kind intelligible. That means that, from an ontological point of view it is not the Anthropocene, strictly speaking, that is a Hyperobject, but the Technosphere that supports it.

This last notion was introduced by Peter Haff, a U.S. civil and environmental engineer. In his opinion «(...) the Technosphere (...) is a global system whose operation underpins the Anthropocene (...)» (2014a, p. 2). Broadly defined, it corresponds to the «The proliferation of technology across the globe (...)» (Haff, 2014, p. 301), but we can also say, more specifically that the "Technosphere" is

(...) the set of large-scale networked technologies that underlie and make possible rapid extraction from the Earth of large quantities of free energy and

\footnotetext{
${ }^{14}$ We may say, using more technical terms, that a system can have $\mathrm{N}$ "degrees of freedom" if there is $\mathrm{N}$ independent numbers to specify its state. So, imagine, for instance, a glass full of water and plop two blue ink drops on it, and after that, a series of pictures as the ink mixes with the water is taken. Each picture - corresponding to each state of the system - can be represented as a point on a 2-D plot, and if we plot a number of points, showing the temporal dynamics of the system, something like a curve in $2 \mathrm{D}$ space will appear. This result is a representation of a $2 \mathrm{D}$ phase space. The greater $\mathrm{N}$, i.e., the more complex - with more degrees of freedom - the system is, more a high(er)-dimensional phase space will be needed. Now, natural events like storms, tornadoes, hurricanes and similar weather phenomena because extended in space, tend to have phase spaces of bigger magnitude. That means that the description of objects of this kind is quite difficult, because the number of points - or variables - to represent each one of these phenomenon as a (finite) spatial region is very high, or, in other words, that we can "inhabit" such objects (phenomena, systems) without being capable to directly visualize them or apprehend them in wholeness. In the writing of this note, I greatly benefited from the reading of two blog posts: Anonymous (2012) and Benzon (2014).

${ }^{15}$ See also Latour (1996).

${ }^{16}$ Commonly called "Blue Board", a foam used in walls and roofs as thermal insulation and prevention of moisture.
} 
subsequent power generation, long-distance, nearly instantaneous communication, rapid long-distance energy and mass transport, the existence and operation of modern governmental and other bureaucracies, high-intensity industrial and manufacturing operations including regional, continental and global distribution of food and other goods, and a myriad additional 'artificial' or 'non-natural' processes without which modern civilization and its present $7 \times 109$ human constituents could not exist. (idem, pp. 301-302).

Haff invites us to conceive the Technosphere in analogy with the other four major "spheres" - or subsystems - of the Earth System, namely the Lithosphere (rock), Hydrosphere (water), Biosphere (life), and Atmosphere (air).

The Earth System Sciences' paradigm, remember (see note 2), is based on the assumption that our planet is a System - comprised by the just referred four subsystems - with interconnected processes (physical, chemical, and biological), maintaining complicated relationships, with many feedback loops, to store, transfer, and transform matter and energy.

The Technosphere, on the other hand, is non-natural or entirely man-made. It has begun to be built in the First Industrial Revolution - with a vast proliferation of all sorts of machines and manufactured objects - around mid- $18^{\text {th }}$ century, and become widely operative after the "Great Acceleration" - globalization of a series of environmental and socioeconomical trends - in the mid-20 $0^{\text {th }}$ century (see below) (Haff 2014, pp. 301, 303; and Morton, 2013, pp. 4-5).

This artificial sphere exhibits now a planetary scale and pleonexic behavior, i.e., an extreme voracity for the material resources of the other four natural spheres. Moreover, because its activities are provoking a depletion of those resources at an ever-increasing rate and its recycling capacity has been very poor, not only it poses a threat to the subsistence of the other spheres, but also risks its self-sustainability and survival.

Haff's Technosphere, therefore, attained the status of a quasi-transcendental, a contingent condition of possibility for Nature, Civilization and Humankind. It possesses the mentioned five fundamental properties of a Hyperobject: viscosity, because technology "sticks" to everything we experience, think, do and imagine, or, in other words, it shapes our entire existential condition; nonlocality, because we inevitably inhabit a technological space much vaster than we can perceive and embrace; temporal undulation because technology affects us in a way that precedes and exceeds our own individual and collective life span; phasing because technology determines most (if not 


\section{The Anthropocene: scientific meaning and philosophical significance}

all) of the trajectories for our existence(s); and interobjectivity, because technological objects, or the entire Technosphere itself, are intrinsically hybrid, i.e., composed of corporeal entangled and interacting objects, either human and non-human, ecological and sociological, natural and artificial, sentient and non-sentient.

\subsection{The Anthropocene as a Technical image}

Pulizzi (2014) claimed that «(...) the Anthropocene only exists thanks to complex climate simulations run on arrays of microprocessors computing in parallel. (...) is not so much a historical event as it is the product of a computer simulation (...)» (p. 83) and suggested, following Flusser ([1985] 2011), that we can describe such computationally generated artifact as a "Technical image" (technisches Bild) (Pulizzi, 2014: 85).

Czech-born philosopher - later naturalized Brazilian - Vilem Flusser developed in his essay Into the Universe of Technical Images (2011) a theory of the "Technical images". According to him, images can be defined, in general, as mediations between the world and us, and divided into two broad categories: (a) “Traditional images" produced through observation and depiction of objects; (b) “Technical images” generated through calculation and computation of conceptualized data. The images of the first type were (wrongly) supposed to be descriptive and to represent the world, and the images of the second kind are to be prescriptive and to project and construct it. In each case, images constitute means (media) created and used to bring stability to the relation between human beings and world. Images give meaning (order) to the world, and allows human beings to guide themselves in the world and adapt to it. What happens, in fact, is that images are made of data, they are data structures, and therefore informative and ultimately a source of knowledge about the world.

Traditional images abstract data from the world to transform it (through codification) into information - convert four-dimensional events from the outside world onto two-dimensional objects: surfaces (e.g., drawing, photography). Technical images, in turn, abstract concepts and transform them into compositions or higher-order abstract concepts - convert one-dimensional elements of text onto dimensionless synthetic structures (e.g., arrays of pixels on screens). Flusser argued that in the development of our cultural history the transition from the traditional images to the Technical images was mediated by the influx of the texts - conversion of two-dimensional objects or surfaces 


\section{João Ribeiro Mendes}

onto one-dimensional objects or lines (segments of points) - to overcome excessive "iconolatry".

Those means - Traditional images, texts and Technical images - not only introduced successive layers of detachment from our concrete experience, as they have also allowed greater power to shape the world and to adapt it to us. Even though Flusser claims that technical images are not representations, but projections, if they are to have any informational value, they must have some representational character, that is, they must correlate with something that remains transcendent to them - real things, besides texts or Traditional images.

What seems to be distinctive of the Technical images is that they are «(..) a human product (...) (idem, p. 18) and «(...) owe their existence to technical apparatuses.» (idem, p. 7). These technical apparatuses - material equipment (devices, instruments, tools, machines, engines, etc.) and organizational structures and systems - «(..) are meant to produce, store, and distribute information.», i.e., to work as «(...) reservoirs of information (...)» (idem, p. 18), and developed to «(...) grasp the ungraspable, visualize the invisible, and conceptualize the inconceivable.» (idem, p. 16).

According to Flusser, such «(...) apparatuses are essential for the production of technical images.» (ibidem). Yet, they do not only seem to do more than a telescope or a microscope, which bring to our presence entities that are too far away or are too small to be seen by the naked eye, but also seem to do more than a statistical tool disclosing patterns within data or extracting information from them. The apparatuses that produce Technical images "conceptualize" the abstracted information and "theorize" upon the generated concepts - conceptualization and theorization are made by human written software programs with built-in algorithms. That is why Flusser says that «(...) technical images are actually mosaics (...) models that give form to a world and a consciousness that has disintegrated; they are meant to "inform" that world.» (idem, p. 172), although evolving dialogically, more than dialectically, i.e., «(...) by means of feedback between themselves and their receivers.» (ibidem).

Technical images, thus, are compared phenomenologically to mosaics and epistemologically to models. They are compositions not representations, interpretations not descriptions. Accordingly, we may say that the Anthropocene is a mosaic and a model, a Technical image.

It seems implicit in Flusser's view that the basic stuff of the world is an entanglement of highly dynamic and constantly changing processes and entities (or substances), and that if we want to have access to that ontological flux we need to create 
(temporary) stabilizers, i.e. "images". More recently, however, since the beginnings of Modernity, this stabilizing (technical) power become increasingly a reifying (technological) power.

The concept of "Anthropocene", as already said, was crafted to refer the most recent non-analogue state of the Earth System in which the aggregated results of the activities of individuals of our species are producing great changes on Earth's major subsystems. But this is only the "big(gest) picture", a sort of high-level (mosaic-model) Technical image. How, then, was this Technical image composed? A possible answer is with other Technical images of lower level.

A first candidate to be one of those less broad Technical images is the so-called "Great Acceleration". It was introduced by Steffen, Sanderson, Tyson, Jäger, Matson, Moore III, Oldfield, Richardson, Schellnhuber, Turner II, \& Wasson (2004), consisting of 12 graphs representing socio-economic trends from 1750 to 2000 plus other 12 graphs showing Earth System trends in the same period. In Steffen, Broadgate, Deutsch, Gaffney, \& Ludwig (2015) all the 24 graphs were updated to 2010. What they revealed is that:

Only beyond the mid-20th century is there clear evidence for fundamental shifts in the state and functioning of the Earth System that are beyond the range of variability of the Holocene and driven by human activities. Thus, of all the candidates for a start date for the Anthropocene, the beginning of the Great Acceleration is by far the most convincing from an Earth System science perspective. (Steffen et alii, 2015, p. 1).

Félix Pharand-Deschênes of Globaïa - a non-profit NGO dedicated to the illustration and cartography of our planet - created this stylized summary of all the graphs:

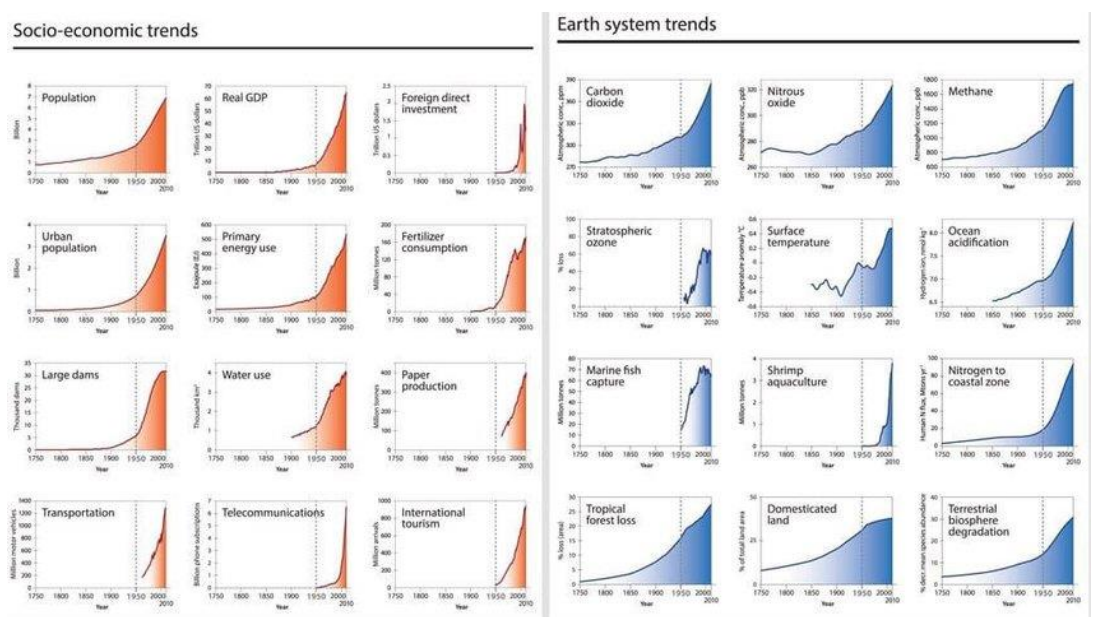

Source: Steffen et alii $(2015: 84,86)$ 


\section{João Ribeiro Mendes}

The second one, named "Planetary Boundaries", appeared for the first time in Rockström, Steffen, Noone, Persson, Chapin III, Lambin, Lenton, Scheffer, Folke, Schellnhuber, Nykvist, de Wit, Hughes, van der Leeuw, Rodhe, Sörlin, Snyder, Costanza, Svedin, Falkenmark, Karlberg, Corell, Fabry, Hansen, Walker, Liverman, Richardson, Crutzen, \& Foley (2009). It was proposed to define the environmental nine limits within which humanity can safely operate. In Steffen, Richardson, Rockström, Cornell, Fetzer, Bennett, Biggs, Carpenter, de Vries, de Wit, Folke, Gerten, Heinke, Mace, Persson, Ramanathan, Reyers, \& Sörlin (2015) updating paper, besides the transgression of the limits of climate change, the loss of biosphere integrity - both understood as "core boundaries" -, and the functioning of the global biogeochemical cycles (phosphorus and nitrogen), already recognized in the 2009 study, a fourth boundary, that of land use, was also identified as having been crossed. We may interpret those results as Johan Rockström (the Stockholm Resilience Centre) and Will Steffen (Australian National University), and their team did: they are clear evidence that the human activity is being main driver to get Earth System into a post-Holocene state.

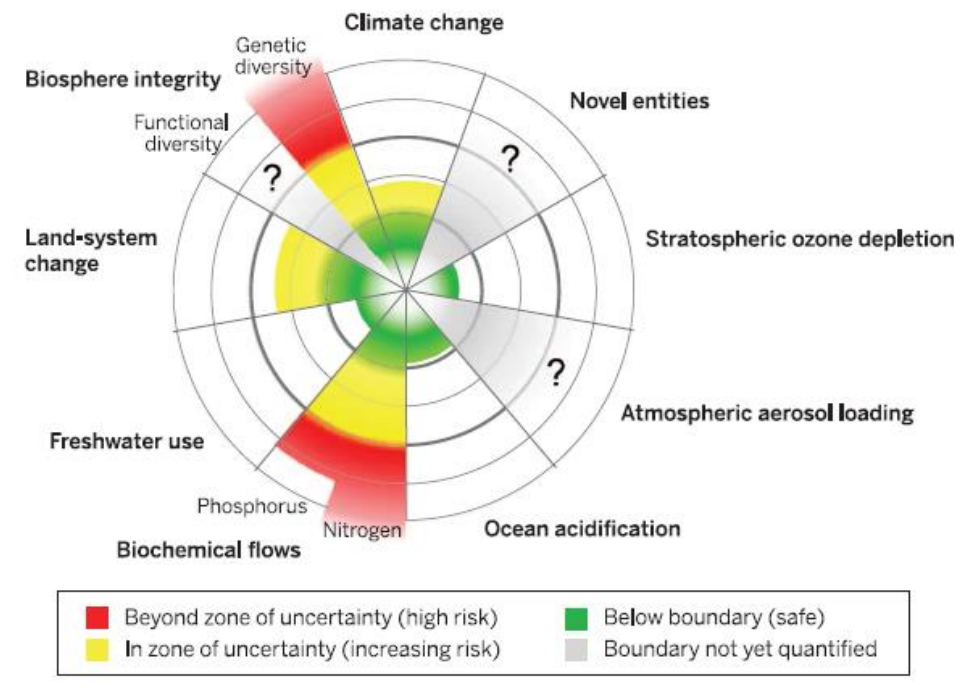

Source: Steffen et alii (2015, p. 736.)

These are, of course, just two lower-level (or smaller) Technical images that make part of the Anthropocene or Technical image, but several other, with different orders and degrees of complexity are needed to compose that mosaic-model. All of them are engendered using a multitude of technical apparatuses: devices to detect, measure and record properties of events taking place in the natural and the social environments - they 


\section{The Anthropocene: scientific meaning and philosophical significance}

codify their properties into data; engines to process or compute the data collected and codified by those "sensors"; analytical instruments to transform data into information; critical tools to attribute meaning to information and convert into knowledge. ${ }^{17}$

To give just one example: there is a network of hundreds of stations scattered around the world daily gathering data on $\mathrm{CO}_{2}$ emissions levels - they use spectroscopic and chemical sensors of carbon dioxide gas; the data are shared and compared to find patterns in them - all the stations have been reporting a trend similar to the so-called Keeling curve ${ }^{18}$; unless we prefer to believe in amazing coincidences, if all the stations diachronically and synchronically report the same rising trend on $\mathrm{CO}_{2}$ emissions levels we perhaps have good reasons to believe that all that stored and computed data gives us an information about the state of the ecological environment; going further and conceptualizing that information as indicating an excessive presence of that gas in the atmosphere, i.e., the reaching of a threshold, a tipping point or the crossing of an ecoenvironmental boundary, having become a menace to human health, corresponds to transmuting it into significant knowledge.

Technical mages are as interpretative as creative. Without them we couldn't have access to the world, not to say we couldn't dwell in it. Through them hidden parts of the structure of the world and concealed features of its dynamics are bring forth as much as are arranged. This is not idealism, because the world has resisted and repelled, once and again, unreal versions of itself, naturally eliminating them.

Big data, vast information, and enormous knowledge, therefore, are needed to compose the Anthropocene Technical image. Nonetheless, we do not have yet a detailed, precise understanding of their entwining. This is one of the reasons why we still don 't have an adequate or robust onto-epistemology for the Anthropocene as Hyperobject and Technical image. That will be a task for future Philosophy.

\footnotetext{
${ }^{17}$ This passage in Michael Lynch (2016) clearly distinguishes the three concepts: «Data is not the same thing as information. (...) bits of code aren 't themselves information; information is what we extract from those bits. They are the meaningful leftovers after we filter out the noise. (...) Yet not all information is good information; information alone still doesn 't amount to knowledge.» (p. 6). In other words: data are raw uninterpreted symbols; information results from the adding of context and meaning to data; and knowledge adds the way how to adequately use the information.

${ }^{18}$ Measurements of carbon dioxide in the Earth's atmosphere being made since 1958 at the Mauna Loa Observatory on Hawaii have shown its unceasing accumulation. The graphical representation of that data along more than 60 years is known as a (Charles David) Keeling Curve, named after the scientist who started the monitoring program and supervised it until his death in 2005.
} 


\section{João Ribeiro Mendes}

\section{References:}

Angus, I. (2016). Facing the Anthropocene: Fossil Capitalism and the Crisis of the Earth System. New York: Monthly Review Press.

Anonymous. (2012, April 23). My two minutes hate: hyperobjects. Part \& Palimpsest https://partpalimpsest.wordpress.com/2012/04/23/my-two-minutes-hate-hyperobjects

Benzon, B. (2014, July 25). Reading Hyperobjects 4: Digital Humanities Edition - High Dimensional Spaces and Descriptions. New Savanna. http://newsavanna.blogspot.com/2014/07/reading-hyperobjects-4-digital.html

Blasdel, A. (2017, June 15). “A reckoning for our species": the philosopher prophet of the Anthropocene. The Guardian. https://www.theguardian.com/world/2017/jun/15/timothy-morton-anthropocenephilosopher

Bonneuil, C. \& Fressoz, J.-B. (2016). The Shock of the Anthropocene. New York: Verso.

Crutzen, P. \& Stoermer, E. (2000). The “Anthropocene." Global Change Newsletter 41: pp. 17-18.

Crutzen, P. (2002). Geology of mankind. Nature, 415(6867): p. 23.

Crutzen, P. \& Steffen, W. (2003). How long have we been in the Anthropocene era? Climatic Change, 61(3): pp. 251-257.

Federau, A. (2016). Philosophie de l'Anthropocène. Interprétations et épistémologie. Université de Lausanne, Faculté des géosciences et de l'environnement. $\mathrm{PhD}$ thesis.

Flusser, V. ([1985] 2011). Into the Universe of Technical Images. Edited by Mark Poster. Translated by Nancy Ann Roth. Minneapolis and London: University of Minnesota Press. (Orig.: Ins Universum der technischen Bilder, Göttingen: European Photography). 


\section{The Anthropocene: scientific meaning and philosophical significance}

Galison, P. (1997). Image and Logic: A Material Culture of Microphysics. Chicago: University of Chicago Press.

Hacking, I. ([1984] 2002). Historical Ontology (pp. 27-50). Cambridge (Massachusetts): Harvard University Press. (Orig.: Five parables. In Philosophy in context, Richard Rorty, Jerry Schneewind, and Quentin Skinner (Eds.), Cambridge, Cambridge University Press, pp. 103-124).

Haff, P. (2014). Technology as a geological phenomenon: implications for human wellbeing. In: Waters, C.N., Zalasiewicz, J., Williams, M., Ellis, M.A., Snelling, A. (Eds). A Stratigraphical Basis for the Anthropocene. Geological Society (pp. 301-309). London: Special Publications 395.

Haff, P. (2014a). Humans and technology in the Anthropocene: Six rules. The Anthropocene Review 1: pp. 1-10.

Hamilton, C. \& Grinevald, J. (2015). Was the Anthropocene anticipated? The Anthropocene Review, 2(1): pp. 1-14.

Hare, L. (2015). The Anthropocene Trading Zone. The New Conservation, Big Data Ecology, and the Valuation of Nature. Environment and Society: Advances in Research, 6: pp. 109-127;

Latour, B. (1996). On interobjectivity, in Mind, culture and activity, 3(4): pp. 228-245.

Lewis, S. and Maslin, M. (2015). Defining the Anthropocene. Nature, 519: 171-80.

Lynch, M. (2016). The Internet of Us: Knowing More and Understanding Less in the Age of Big Data. New York: Liverite/W. W. Norton.

Morton, T. (2013). Hyperobjects: Philosophy and Ecology after the End of the World. Minneapolis: University of Minnesota Press.

Pulizzi, J. (2014). Predicting the End of History Mathematical Modeling and the Anthropocene. Minnesota Review, 83: pp. 83-92. 


\section{João Ribeiro Mendes}

Rice, M. (2017). The "Anthropocene" Misnomer and an Alternative: On De-obfuscating a Discombobulating Descriptor. Conference Paper presented at the Annual Conference of the AAL -"Literary Environments", At Griffith University, Gold Coast, Queensland, Australia https://www.researchgate.net/publication/318447873_The_'Anthropocene'_Misnomer_ and_an_Alternative_On_De-obfuscating_a_Discombobulating_Descriptor

Rockström, J., Steffen, W., Noone, K., Persson, Å., Chapin III, F., Lambin, E., Lenton, T., Scheffer, M., Folke, C., Schellnhuber, H., Nykvist, B., de Wit, C., Hughes, T., van der Leeuw, S., Rodhe, H., Sörlin, S., Snyder, P., Costanza, R., Svedin, U., Falkenmark, M., Karlberg, L., Corell, R., Fabry, V., Hansen, J., Walker, B., Liverman, D., Richardson, K., Crutzen, P. \& Foley, J. (2009). A safe operating space for humanity. Nature, 461: pp. 472475.

Ruddiman, W. (2003). The anthropogenic greenhouse era began thousands of years ago. Climatic Change, 61(3): pp. 261-293.

Rull, V. (2018). What If the "Anthropocene" Is Not Formalized as a New Geological Series/Epoch? Quaternary 1(24): pp. 1-7.

Schwägerl, C. \& Crutzen, P. (2013). A Huge Variety of Possibilities: Interview with Nobel Laureate Paul Crutzen on his Life, his Career in Research, and his Views on the Anthropocene Idea. Welcome to the Anthropocene: The Earth in Our Hands. Environment Society Portal (http://www.environmentandsociety.org/exhibitions/anthropocene/hugevariety-possibilities-interview-nobel-laureate-paul-crutzen-his-life; 7.3.2017).

Steffen, W., Sanderson, A., Tyson, P. Jäger, J., Matson, P., Moore III, B., Oldfield, F., Richardson, K., Schellnhuber, J., Turner II, B. \& Wasson, R. (2004). Global Change and the Earth System: A Planet Under Pressure. The IGBP Book Series. Berlin, Heidelberg, New York: Springer Verlag.

Steffen, W. (2013). Commentary: Crutzen and Stoermer in the Anthropocene. In Libby Robin, Sverker Sörlin \& Paul Warde (Eds.), The Future of Nature: Documents of Global Change (pp. 486-490), New Haven, CT, Yale University Press. 
Steffen, W., Broadgate, W., Deutsch, L., Gaffney, O. \& Ludwig, C. (2015). The trajectory of the Anthropocene: The Great Acceleration. The Anthropocene Review, 2(1): 81-98.

Steffen, W., Richardson, K., Rockström, J., Cornell, S., Fetzer, I., Bennett, E., Biggs, R., Carpenter, S., de Vries, W., de Wit, C., Folke, C., Gerten, D., Heinke, J., Mace, G., Persson, L., Ramanathan, V., Reyers, B. \& Sörlin, S. (2015). Planetary Boundaries: Guiding human development on a changing planet. Science, 347(6223): p. 736.

Syvitski, J. (2012). Anthropocene: An Epoch of Our Making. Global Change, 78: pp. 1215.

University of Leicester-Press Office. (2016, August 29). Media note: Anthropocene Working Group (AWG) [press release]. https://www2.le.ac.uk/offices/press/pressreleases/2016/august/media-note-anthropocene-working-group-awg

Para citar:

Mendes, J. (2020). The Anthropocene: scientific meaning and philosophical significance. Anthropocenica. Revista de Estudos do Antropoceno e Ecocrítica 1: pp. 71-89. 